\title{
ANALISIS METAKOGNISI SISWA BERBASIS LESSON STUDY FOR LEARNING COMMUNITY (LSLC) DITINJAU DARI GAYA KOGNITIF
}

\author{
Saiful Saiful' ${ }^{1}$, Hobri Hobri'2 ${ }^{2}$ Mohammad Tohir ${ }^{1}$ \\ 1Universitas Ibrahimy, Situbondo, Indonesia \\ 2Universitas Jember, Indonesia \\ saiful10121978@gmail.com
}

\begin{abstract}
:
This research aims to analyze students' metacognition in learning mathematical problem solving based on Lesson Study for Learning Community (LSLC) if reviewed from reflective and impulsive cognitive styles. The research method employed in this research is descriptive qualitative. The data collection is done by observation, tests, interviews, think aloud and documentation. The test is given to 30 students when an open class in class VII of MTs Miftahul Hidayah. Based on the test results, students are grouped into two in reviewed from reflective and impulsive cognitive styles. Three students were selected from each group to be interviewed and deepened through a thinkaloud technique. The form of data analysis is classified into induction and reduction theory. The results of this research indicates that 18 students (60\%) have reflective cognitive styles and 12 students (40\%) have impulsive cognitive styles. Reflective cognitive style students, the scores obtained are better by using a relatively long time and can do aspects of metacognition well. While the scores obtained by impulsive cognitive style students are lower with the use of the time that is relatively faster and unable to perform aspects of metacognition well.
\end{abstract}

Keywords: Metacognition, cognitive style, Lesson Study, Learning Community

\section{PENDAHULUAN}

Kegiatan pembelajaran matematika di abad ke-21 memiliki peran penting dalam dunia pendidikan agar siswa dapat menguasai keterampilan berpikir kritis, berpikir kreatif dan inovatif, serta mampu berkomunikasi dan berkolaborasi antar sesama siswa dan orang lain. Hal ini sejalan dengan pembelajaran abad 21 (P21, 2014), yaitu pembelajaran yang menuntut siswa untuk memiliki kompetensi dalam berpikir kritis, berpikir kreatif, komunikatif, dan kolaboratif. Menurut Saiful, Susanto, \& Hobri (2019) mengatakan bahwa matematika sebagai salah satu mata pelajaran yang memegang peranan yang sangat penting dalam pendidikan. Matematika merupakan sarana berpikir untuk menumbuh-kembangkan daya nalar, cara berpikir logis, sistematis dan kritis. Menurut hasil penelitian yang didapat oleh Anggraena (2019) menunjukkan bahwa terhadap problematika pembelajaran matematika terutama kesulitan siswa terhadap materi operasi bentuk aljabar, diantaranya; kurangnya materi prasyarat, kesalahan konsep dan kesalahan prosedur. Kelemahan pembelajaran matematika saat ini para siswa tidak dapat menghubungkan konsep-konsep matematika di sekolah dengan pengalaman mereka sehari-hari. Oleh karena itu, perlu adanya variasi dan inovasi dalam pembelajaran matematika agar siswa merasa nyaman di dalam kelas. Hal ini sesuai dengan pengdapat Maswar (2019) mengatakan bahwa Metode belajar yang variatif, inovatif dan menarik menjadikan proses belajar matematika di kelas menjadi terhibur dan menyenangkan siswa. Upaya yang dapat dilakukan adalah memahami 
kesulitan yang dialami siswa dalam mempelajari konsep-konsep matematika, bagaimana siswa belajar, proses memahami dan langkah-langkah belajarnya serta bagaimana siswa berpikir tentang proses pemikiran mereka. Hal tersebut secara umum dikenal sebagai metakognisi, merupakan istilah yang diperkenalkan oleh John Flavell, seorang psikolog perkembangan dari Universitas Stanford. Menurut Kathwohl (Tohir, 2017) Pengetahuan metakognisi adalah pengetahuan tentang kognisi secara umum sama dengan kesadaran dan pengetahuan tentang kognisidiri seseorang, sedangkan ketrampilan metakognisi tentang kesadaran seseorang untuk melakukan perencanaan, mengikuti perkembangan, dan memantau proses belajarnya.

Mahdavi (2014) menyatakan bahwa sebagian besar peneliti sekarang telah mengkonseptualisasikan metakognisi mempunyai dua komponen utama yaitu, metacognitive knowledge dan metacognitive control. Metacognitive knowledge terdiri dari tiga aspek yang terkait erat, yaitu: 1) Declarative knowledge, merupakan pengetahuan, keterampilan, dan strategi penting untuk menyelesaikan tugas dengan sukses dalam berbagai kondisi. 2) Procedural knowledge, merupakan pengetahuan tentang bagaimana menerapkan prosedur seperti strategi pembelajaran atau tindakan untuk memanfaatkan pengetahuan deklaratif dalam mencapai tujuan. 3) Conditional knowledge, disebut sebagai pengetahuan tentang kapan dan mengapa menerapkan berbagai prosedur, keterampilan, dan tindakan atau strategi kognitif. Sedangkan metacognitive control adalah elemen utama kedua dari metakognisi untuk mengendalikan pemikiran atau pembelajaran mereka sendiri. Ini mencakup setidaknya tiga aspek penting, yaitu: 1) Planning, termasuk pemilihan strategi dan prediksi yang tepat untuk mencapai tujuan. 2) Monitoring, mengacu pada analisis kritis terhadap efektivitas strategi atau rencana yang sedang dilaksanakan. 3) Evaluation, mengacu pada pemeriksaan kemajuan yang sedang dibuat menuju tujuan yang dapat memicu perencanaan, pemantauan dan evaluasi lebih lanjut. Sedangkan menurut Tohir (2019) mengatakan bahwa metakognisi memiliki peranan penting dalam mengatur dan mengontrol proses kognitif seseorang dalam belajar dan berpikir.

Metakognisi merupakan suatu aktifitas mental yang tidak dapat diajarkan tetapi dapat ditanamkan dalam pembelajaran atau pelatihan. Hal ini sesuai dengan pendapat Tohir, Susanto, Hobri, Suharto, \& Dafik (2018) mengatakan bahwa aktifitas mental yang telah tertanam dengan baik pada diri seseorang ketika kegiatan pembelajaran berlangsung, maka akan memuncul proses berpikirnya dengan baik pula sehingga kemampuan metakognisi berkaitan erat dengan kegiatan belajar siswa Menurut Efendi (Tohir \& Wardani, 2017) yang menjelaskan bahwa kegiatan pembelajaran memuat rangkaian kegiatan yang harus dilakukan oleh peserta didik secaraberurutan untuk mencapai kompetensi dasar. Kegiatan pembelajaran di kelas melibatkan kemampuan pemahaman siswa dengan gaya kognitif yang berbeda. Cintamulya \& Mawartiningsih (2019) mengatakan bahwa gaya kognitif dapat dibedakan berdasarkan kecepatan waktu untuk menanggapi rangsangan yang mencakup gaya kognitif reflektif dan impulsif. Bahkan Muhtarom (Utami \& Indriana, 2018) mensyaratkan bahwa dua aspek penting diambil dalam mengukur gaya kognitif reflektif dan impulsif: jumlah waktu yang dibutuhkan dan keakuratan jawaban. Untuk mengetahui gaya kognitif siswa dapat diamati pada saat open class berbasis Lesson Study for Learning Community (LSLC). Menurut 
Isoda (Saiful, 2019) mengatakan bahwa Lesson study adalah kegiatan ilmiah untuk guru yang mencoba mengembangkan teori mereka untuk mengembangkan dan berbagi praktek-praktek yang baik. Pada lesson study guru berkolaborasi untuk mempelajari isi dan instruksi pembelajaran dengan mengamati pelajaran dan mendiskusikannya. Learning community itu sendiri merupakan hasil dari lesson study, untuk meningkatkan aktifitas belajar siswa sehingga bisa saling bekerjasama dalam bentuk kolaborasi dan kolegalitas (Bjuland \& Mosvold, 2015).

Penelitian sebelumnya yang dilakukan oleh Purwaningsih, Astuti, Nugraheni, \& Rizkyaningtyas (2019) bertujuan untuk menggambarkan karakteristik pemikiran intuitif siswa SMP yang memiliki gaya kognitif impulsif dan refleksif untuk memecahkan masalah objek 3D berdasarkan tahapan Polya. Faradillah, Hadi, \& Tsurayya (2018) untuk mendeskripsikan tingkat kemampuan penalaran matematis guru magang dalam menyelesaikan masalah matematika non-rutin berdasarkan gaya kognitif. Hobri, Romlah, Prihandoko, Safitri, \& Nazareth (2018) bertujuan untuk menganalisis keterampilan metakognitif siswa melalui penerapan pembelajaran pemecahan masalah matematika berdasarkan Lesson Study for Learning Community. Sedangkan penelitian ini bertujuan untuk menganalisis kemampuan metakognisi siswa dalam pembelajaran pemecahan masalah berbasis LSLC ditinjau dari gaya kognitif reflektif dan impulsif. Adapun akktivitas metakognisi yang dilakukan kepada siswa dalam memecahkan masalah matematika didapat dengan susunan indikator ketercapaian metakognisi yang diuraikan pada tabel 1 berikut ini.

Tabel 1. Indikator ketercapaian metakognisi siswa

\begin{tabular}{|c|c|}
\hline $\begin{array}{c}\text { Aspek } \\
\text { Metakognisi }\end{array}$ & Indikator Ketercapaian Metakognisi Siswa \\
\hline Planning & $\begin{array}{l}\text { - Menuliskan yang diketahui dan ditanyakan } \\
\text { - Menyebutkan pilihan-pilihan strategi dalam menyelesaikan } \\
\text { masalah } \\
\text { - Menemukan strategi yang tepat dan masuk akal dalam } \\
\text { menyelesaikan masalah. }\end{array}$ \\
\hline Monitoring & $\begin{array}{l}\text { - Menganalisis pilihan strategi untuk memilih prosedur } \\
\text { penyelesaian. } \\
\text { - Menduga jawaban terbaik berdasarkan prosedur } \\
\text { penyelesaian yang dipilih } \\
\text { - Menyebutkan alasan yang tepat terhadap pilihan prosedur } \\
\text { penyelesaian yang dipilih. } \\
\text { - Menyebutkan alasan bahwa jawaban yang didapat } \\
\text { merupakan jawaban terbaik. }\end{array}$ \\
\hline Evaluation & $\begin{array}{l}\text { - Memeriksa kembali secara menyeluruh terhadap prosedur } \\
\text { penyelesaian yang telah digunakan } \\
\text { - Menarik kesimpulan yang valid terhadap jawaban yang } \\
\text { didapat } \\
\text { - Mengevaluasi hasil pekerjaan yang telah didapat }\end{array}$ \\
\hline
\end{tabular}




\section{METODE PENELITIAN}

Penelitian ini merupakan penelitian deskriptif kualitatif. Metode yang digunakan adalah case study, yaitu bagian dari metode kualitatif yang hendak mendalami suatu kasus tertentu secara lebih mendalam dengan melibatkan pengumpulan beraneka sumber informasi (Semiawan, 2018). Dalam penelitian ini kasus yang hendak didalami adalah kesulitan terhadap materi bentuk aljabar yang diungkap dengan melakukan analisis metakognisi siswa dalam pembelajaran pemecahan masalah berbasis LSLC apabila ditinjau dari gaya kognitif reflektif dan impulsif.

Pengumpulan data dilakukan dengan observasi, tes, wawancara, think aloud dan dokumentasi. Observasi dilakukan pada setiap tahapan lesson study yaitu tahap Plan, Do dan See. Pada tahap Plan adalah pembuatan Rencana Pelaksanaan Pembelajaran (RPP) dan Lembar Kerja Siswa (LKS) bersama guru model. Pada tahap Do dilakukan pada saat open class terhadap aktifitas siswa. Pada tahap See dilakukan refleksi terhadap proses pembelajaran saat open class. Tes diberikan kepada siswa ketika open class di kelas VII MTs Miftahul Hidayah. Dari hasil tes, siswa dikelompokkan menjadi dua berdasarkan gaya kognitifnya. Dua siswa dipilih dari masing-masing kelompok untuk diwawancarai dan diperdalam melalui teknik think aloud. Sedangkan dokumentasi untuk merekam semua kegiatan pada setiap tahapan lesson study. Analisis data dilakukan secara deskriptif kualitatif, berupa teori induksi dan reduksi data.

Penyajian data dalam penelitian kualitatif dapat dibuat dalam deskripsi singkat dan hubungan antara kategori, bentuk paling umum dari penyajian data dalam penelitian kualitatif hingga saat ini, adalah teks naratif (Tohir, Abidin, Dafik, \& Hobri, 2018). Sedangkan dalam penelitian ini, penyajian data meliputi klasifikasi dan identifikasi data, diikuti oleh pengumpulan data yang diorganisasikan dan dikategorikan untuk menarik kesimpulan. Menurut Sugiyono (Tohir \& Wardani, 2017) mengatakan bahwa keabsahan data dalam suatu penelitian dapat diuji dengan empat hal, yaitu meliputi: derajat kepercayaan (credibility), keteralihan (transferability), kebergantungan (dependability), dan kepastian (confirmability).

\section{HASIL DAN PEMBAHASAN}

Tahapan penerapan LSLC diawali dengan plan. Pada tahap ini melakukan perumusan strategi pembelajaran dan penyusunan instrumen pembelajaran berupa Rencana Pelaksanaan Pembelajaran (RPP) dan Lembar Kerja Siswa (LKS). Salah satu tujuan pembelajaran akan dapat dicapai dengan melalui penyusunan RPP yang baik dan dapat menyediakan pengalaman belajar peserta didik yang baik (Tohir \& Wardani, 2017). Melalui penyusunan RPP yang dilengkapi dengan LKS, dan instrumen penilaian diharapkan dapat meningkatkan aktifitas siswa sehingga bisa saling bekerja dalam mencapai tujuan pembelajaran. Terdapat empat orang yang mengikuti tahap ini yaitu guru matematika kelas VII sebagai guru model, sedangkan dua guru mata pelajaran lain dan peneliti sebagai observer. Guru model menjelaskan rencana proses pembelajaran kepada observer.

Pada tahap open class, guru model melaksanakan proses pembelajaran di kelas dengan materi operasi bentuk aljabar. Sedangkan dua guru mata pelajaran lain dan peneliti melakukan observasi dengan menggunakan instrumen observasi terhadap 
aktifitas siswa. Menurut Hobri, Septiawati, \& Prihandoko (2018) mengatakan bahwa open class adalah salah satu kegiatan LSLC yang dilanjutkan dengan refleksi dari hasil pengamatan aktivitas siswa.

Tahap terakhir adalah refleksi terhadap proses pembelajaran dengan melaporkan hasil observasi. Refleksi adalah tahap "melihat" dalam LSLC yang berfokus pada bagaimana siswa belajar, sementara pengamatan tentang bagaimana guru mengajar serta penguasaan materi pembelajaran akan diberikan persentase yang sangat kecil (Hobri et al., 2018). Semua observer melaporkan hasil obervasinya dan kesimpulannya menyatakan bahwa guru sangat terbantu dalam proses pembelajran dengan bantuan Rencana Pelaksanaan Pembelajaran (RPP) dan Lembar Kerja Siswa (LKS), sedangkan siswa menunjukkan aktifitas berupa kerja sama, diskusi dan saling membantu dalam satu kelompok.

Pada penelitian ini, tes yang diberikan pada siswa berupa 4 soal materi operasi bentuk aljabar. Dari hasil tes yang diberikan kepada siswa ketika open class di kelas VII MTs Miftahul Hidayah, siswa dikelompokkan menjadi dua berdasarkan gaya kognitifnya, yaitu siswa bergaya kognitif reflektif dan impulsif. Dari masingmasing kelompok ada 18 siswa (60\%) bergaya kognitif reflektif dan 12 siswa (40\%) bergaya kognitif impulsif. Tiga siswa dipilih dari masing-masing kelompok untuk diwawancarai. Dari siswa bergaya kognitif reflektif yaitu IM (S-1), AK (S-2), dan AG (S-3). Sedangkan siswa bergaya kognitif impulsif yaitu LN (S-4), BM (S-5), dan DR (S-6).

Tabel 2. Gaya Kognitif Subjek

\begin{tabular}{ccccc}
\hline Kode & Subjek & Skor & $\begin{array}{c}\text { Waktu } \\
\text { (menit) }\end{array}$ & $\begin{array}{c}\text { Gaya } \\
\text { Kognitif }\end{array}$ \\
\hline Siswa A & IM & 90 & 80 & Reflektif \\
Siswa B & AK & 80 & 70 & Reflektif \\
Siswa C & AG & 70 & 70 & Reflektif \\
Siswa D & LN & 70 & 60 & Impulsif \\
Siswa E & BM & 60 & 50 & Impulsif \\
Siswa F & DR & 50 & 50 & Impulsif \\
\hline
\end{tabular}

Berdasarkan hasil tes pada tabel 2 diatas, menunjukkan bahwa Siswa A, Siswa B, dan Siswa C memperoleh skor lebih baik dengan waktu yang relatif lebih lama. Skor rata-rata dari Siswa A, Siswa B, dan Siswa C adalah 80 dengan waktu rata-rata 73 menit. Bahkan Siswa A menggunakan waktu dengan maksimal untuk memperoleh skor tetinggi. Sedangkan Siswa D, Siswa E, dan Siswa F memperoleh skor kurang baik dengan waktu yang relatif lebih cepat. Skor rata-rata dari Siswa D, Siswa E, dan Siswa F adalah 60 dengan waktu rata-rata 53 menit. Siswa bergaya kognitif reflektif, skor yang diperoleh lebih baik dengan pengguaan waktu yang relatif lebih lama. Sedangkan siswa bergaya kognitif impulsif, skor yang diperoleh lebih rendah dengan penggunaan waktu yang relatif lebih cepat. Hal ini dipertegas oleh Philip (Widadah, Afifah, \& Pos, 2013) mendefinisikan bahwa siswa impulsif adalah siswa yang dengancepat merespon situasi, namun respon pertama yang diberikan sering salah. Sedangkansiswa reflektif mempertimbangkan banyak 
alternatif sebelum merespon, sehingga tinggikemungkinan bahwa respon yang diberikan adalah benar. Temuan McKinney (Warli, 2014) menunjukkan bahwa anak-anak yang reflektif memproses informasi tugas/masalah lebih efisien dibanding anak-anak impulsif dan mengerjakan lebih sistematis atau mengedepankan strategi. Hasil penelitian ini sejalan dengan hasil penelitian yang didapat oleh Fadiana (2016) menunjukkan bahaw Siswa bergaya kognitif Impulsif membutuhkan waktu yang relatif lebih singkat dari pada siswa bergaya kognitif Reflektif dalam menyelesaikan soal cerita. Hasil penelitian ini juga memperkuat hasil penelitian yang didapat oleh Nasriadi (2019) menunjukkan bahwa Siswa yang memiliki gaya kognitif reflektif cenderung menyelesaikan masalah lebih efesien dibanding siswa yang memiliki gaya kognitif impulsif dan mengerjakan lebih sistematis atau mengedepankan strategi.

Adapun aktifitas metakognisi yang dilakukan siswa bergaya kognitif reflektif dan impulsif dapat diidentifikasi sebagai berikut.

\section{Siswa Bergaya Kognitif Reflektif}

Hasil Jawaban Siswa bergaya kognitif reflektif untuk Siswa A

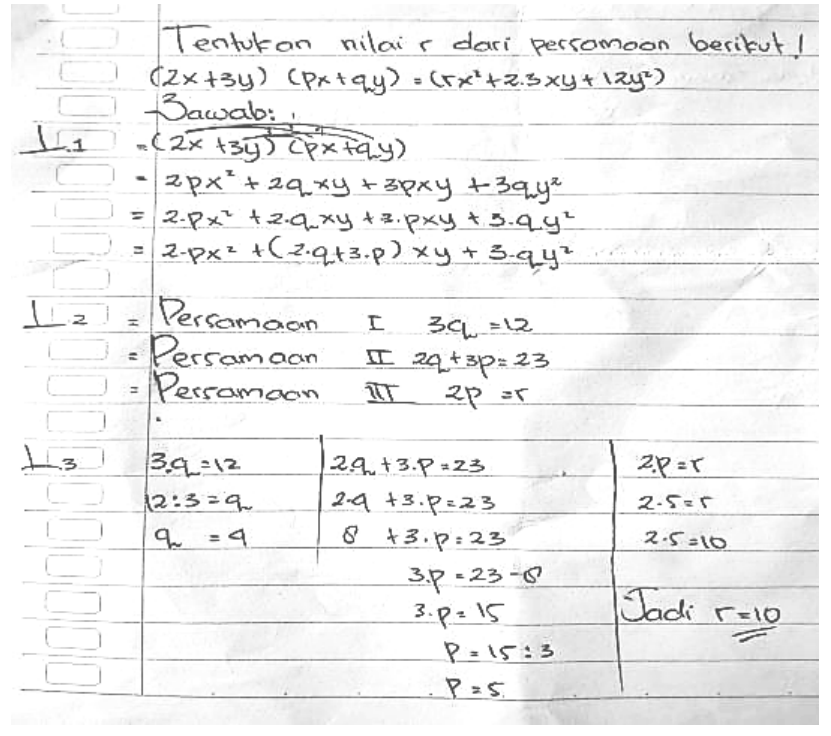

Gambar 1. Hasil Jawaban Siswa A

Berdasarkan hasil jawaban dari Siswa A menarik perhatian peneliti, maka penulis melakukan wawancara khusus kepada siswa tersebut, bagaimana sebenarnya strategi yang digunakan dalam memecahkan masalah matematika terhadap soal tersebut. Berikut hasil wawancaranya.

Peneliti : Apakah kamu memahami maksud dari soal ini?

Siswa A : Ya, saya paham maksudnya pak.

Peneliti : Apakah ada hal yang kurang jelas dari soal ini?

Siswa A : Saya kira sudah cukup jelas maksud soal ini.

Peneliti : Apakah kamu menuliskan hal yang diketahui dan ditanyakan dari soal?

Siswa A : Ya, saya menulis yang diketahui dan ditanyakan. 
Peneliti : Apakah kamu tahu cara mengerjakan soal ini?

Siswa A : Ya, tahu pak (sambil tersenyum)

Peneliti : Mengapa menggunakan cara ini untuk menyelesaikannya? (sambil menunjuk ke jawaban siswa)

Siswa A : karena menurut saya memangharus begitu caranya.

Peneliti : Adakah cara lain yang bisa digunakan untuk menyelesaikan soal?

Siswa A : Saya kira cara ini yang lebih terperinci pak.

Peneliti : Apakah kamu menyusun strategi sebelum mengerjakan soal tersebut?

Siswa A : Ya seperti yang ada pada jawaban itu.

Peneliti : Apakah kamu sudah menduga hasil akhir dari soal?

Siswa A : Ya pak. Menduga langkah-langkahnya sampai hasil akhir.

Peneliti : Apakah kamu mengerjakan soal sesuai dengan rencana atau strategi yang telah kamu susun?

Siswa A : Ya harus sesuai kan pak. Sesuai dengan rencana dan strategi yang telah direncanakan sebelumnya.

Peneliti : apakah ka mu mengecek kembali jawabanmu?

Siswa A : Iya, tapi cuma sebentar se. Soalnya kepala saya kemari sakit.

Berdasarkan hasil wawancara terhadap S-1 menunjukkan bahwa S-1 pada aspek planning, menuliskan hal yang diketahui dan ditanyakan dari soal, menyusun strategi sebelum mengerjakan soal, dan dapat menduga hasil akhir dari soal. Pada aspek monitoring, mengerjakan soal sesuai dengan rencana atau strategi yang telah disusun, memeriksa kesesuaian langkah dengan tujuan, dan dapat mengatasi kesulitan selama mengerjakan soal. Pada aspek evaluation, meyakini langkah pekerjaan sudah sesuai, memeriksa kembali hasil yang telah peroleh, dan dapat memperbaiki kesalahan langkah atau hasil.

Hasil Jawaban Siswa bergaya kognitif reflektif untuk Siswa B

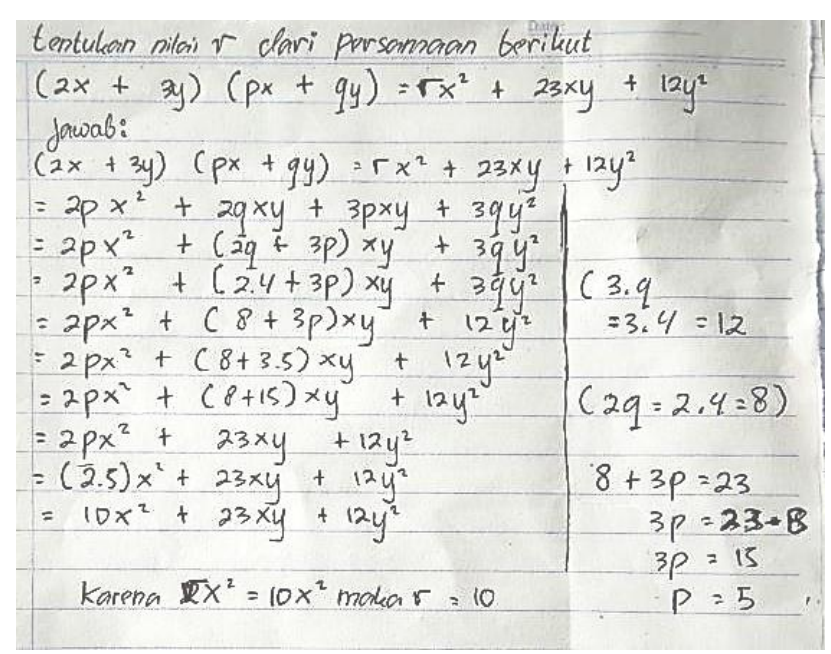

Gambar 2. Hasil Jawaban Siswa B

Berdasarkan hasil jawaban dari Siswa B cukup menarik perhatian peneliti, maka penulis melakukan wawancara khusus kepada siswa tersebut, bagaimana 
sebenarnya proses pemilihan strategi yang digunakan dalam memecahkan masalah matematika terhadap soal tersebut. Berikut hasil wawancaranya.

Peneliti : Apakah kamu menuliskan hal yang diketahui dan ditanyakan dari soal tersebut?

Siswa B : Ya, saya menulis pak.

Peneliti : Apakah kamu menyusun strategi sebelum mengerjakan soal tersebut?

Siswa B : Secara khusus tidak. Tapi saya ikuti sesuai kebutuhan untuk menentukan nilai yang dibutuhkan. Yaitu mencari nilai q terlebih dahulu

Peneliti : Apakah kamu sudah menduga hasil akhir dari soal?

Siswa B : Ya pak. Yaitu menentukan nilai dari r-nya.

Peneliti : Apakah kamu mengerjakan soal sesuai dengan rencana atau strategi yang telah kamu susun?

Siswa B : Ya saya sesuaikan deangan rencana yang hendak saya tulis pak. rencana pertama menyamakan bentuk yang ruas kanan dengan ruas kiri, sehingga nilai $\mathrm{p}$, q dan $\mathrm{r}$ ketemu.

Peneliti : Apakah kamu menemukan kesulitan selama mengerjakan soal?

Siswa B : Kalau kesulitan hanya sedikit pak. Saya kerjakan yang saya ingat dulu materinya.

Peneliti : Sedikit bagaimana?

Siswa B : Ya, agak lama menemukan cara yang paling cepat pak.

Peneliti : Apakah kamu yakin bahwa langkah pekerjaanmu sudah sesuai?

Siswa B : Ya saya yakin benar.

Peneliti : Apakah kamu memeriksa kembali hasil yang telah kamu perolah?

Siswa B : Ya tentu saya periksa, kuwatir ada yang keliru begitu.

Peneliti : Apakah ada hal yang kamu perbaiki?

Siswa B : Iya, sedikit pak

Berdasarkan hasil wawancara terhadap Siswa B menunjukkan bahwa Siswa B pada aspek planning, menuliskan hal yang diketahui dan ditanyakan dari soal, menyusun strategi sebelum mengerjakan soal, namun belum dapat menduga hasil akhir dari soal. Pada aspek monitoring, mengerjakan soal sesuai dengan rencana atau strategi yang telah disusun, memeriksa kesesuaian langkah dengan tujuan, dan dapat mengatasi kesulitan selama mengerjakan soal. Pada aspek evaluation, meyakini langkah pekerjaan sudah sesuai, memeriksa kembali hasil yang telah peroleh, dan dapat memperbaiki kesalahan langkah atau hasil. Sedangkan Siswa $\mathrm{C}$ pada aspek planning, menuliskan hal yang diketahui dan ditanyakan dari soal, mengalami kesulitan dalam menyusun strategi sebelum mengerjakan soal, dan belum dapat menduga hasil akhir dari soal. Pada aspek monitoring, mengalami kesulitan mengerjakan soal sesuai dengan rencana atau strategi yang telah disusun, namun masih memeriksa kesesuaian langkah dengan tujuan, dan dapat mengatasi kesulitan selama mengerjakan soal. Pada aspek evaluation, belum meyakini langkah pekerjaan sudah sesuai, namun masih memeriksa kembali hasil yang telah peroleh, dan dapat memperbaiki kesalahan langkah atau hasil. 
Hasil ini penelitian ini terhadap Siswa bergaya kognitif reflektif menunjukkan bahwa siswa telah melibatkan semua metakognisinya dengan baik ketika ketika memecahkan masalah matematika, dengan dapat menggunakan komponen metakognisi, yaitu pada bagian planning siswa menyadari bahwa pengetahuan awal yang dapat membantu dalam memilih informasi yang terkait dengan materi pada soal tersebut, siswa menyadari terhadap arah pikirannya sendiri bahwa beberapa informasi yang terkait dengan materi tidak semuanya digunakan dalam memecahkan masalah yang adalah, siswa juga menyadari bahwa materi-materi yang terkait akan berguna dan penting dalam memilih satrateri yang tepat; pada bagian monitoring siswa menyadari bahwa apa yang pikirkan akan mempengaruhi arah dari penggunaan strategi yang dipilih, siswa menyadari juga bahwa jawaban yang didapat tidak luput dari ketelitian dalam menjawab soal, siswa menyadari bahwa prosedur penyelesaian yang dilakukan dengan teliti akan mendapatkan jawaban yang benar; pad abagian evaluating siswa menyadari bahwa jawaban yang didapat harus diperiksa kembali atau bisa menggunkan strategi lain untuk mengecek kevalidan jawaban tersebut, siswa menyadari bahwa apa yang dikerjakan akan membawa manfaat kepada orang lain. Hasil penelitian ini memperkuat hasil penelitian yang dilakukam oleh Fitriyah (2015) menunjukkan bahwa proses metakognisi SPS, SLR, dan SPR dalam menyelesaikan soal cerita meliputi planning, monitoring, dan evaluating pada setiap tahap memahami soal, membuat modelmatematika, dan menyelesaikan model matematika adalah hampir sama, yaitu pada bagian planning sadarpengetahuan awal yang dapat membantu; pada bagian monitoring sadar adanya informasi penting yang harus diingat; pada bagian evaluating sadar atas perlunya kembali ke tahap awal ketika mengalami kesulitan.

\section{Siswa Bergaya Kognitif Impulsif}

Hasil Jawaban Siswa bergaya kognitif impulsif untuk Siswa D

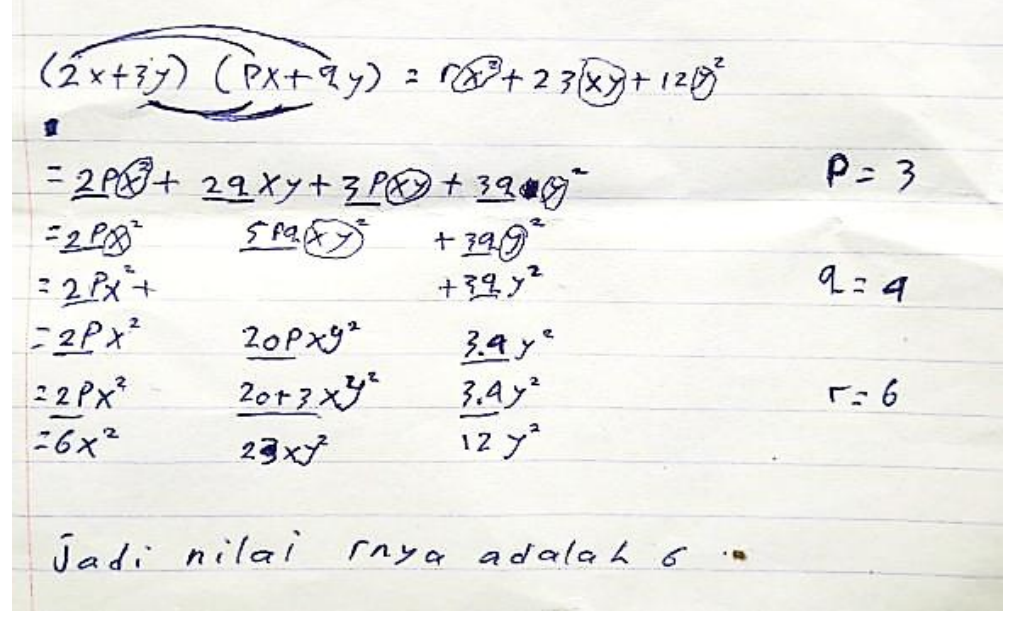

Gambar 3. Hasil Jawaban Siswa D

Berdasarkan hasil jawaban dari Siswa D cukup unik sehingga menarik perhatian peneliti, maka penulis melakukan wawancara khusus kepada siswa 
tersebut, bagaimana sebenarnya proses pemilihan strategi yang digunakan dalam memecahkan masalah matematika terhadap soal tersebut. Berikut hasil wawancaranya.

Peneliti : Apakah kamu menuliskan hal yang diketahui dan ditanyakan dari soal tersebut?

Siswa D : Ya, saya tulis di oret-oretan dulu pak

Peneliti : Apakah kamu menyusun strategi sebelum mengerjakan soal tersebut?

Siswa D : Ya, kalau sudah yakin baru ditulis.

Peneliti : Apakah kamu sudah menduga hasil akhir dari soal?

Siswa D : Belum tahu pak.

Peneliti : Apakah kamu mengerjakan soal sesuai dengan rencana atau strategi yang telah kamu susun?

Siswa D : Saya kerjakan sebisanya pak

Peneliti : Apakah kamu menemukan kesulitan selama mengerjakan soal?

Siswa D : Kesulitan mencari pqr itu pak.

Peneliti : Apakah kamu yakin bahwa langkah pekerjaanmu sudah sesuai?

Siswa D : Yang penting kan berusaha pak

Peneliti : Apakah kamu memeriksa kembali hasil yang telah kamu perolah?

Siswa D : Ya pak

Peneliti : Apakah ada hal yang kamu perbaiki?

Siswa D : Ya pangkatnya, terus ada yang salah tulis pak.

Berdasarkan hasil wawancara terhadap Siswa D menunjukkan bahwa Siswa D pada aspek planning, menuliskan hal yang diketahui dan ditanyakan dari soal, namun tidak menyusun strategi sebelum mengerjakan soal, dan tidak dapat menduga hasil akhir dari soal. Sehingga pada aspek monitoring, mengerjakan soal tidak sesuai dengan rencana atau strategi yang telah disusun, tidak memeriksa kesesuaian langkah dengan tujuan, namun masih dapat mengatasi kesulitan selama mengerjakan soal. Pada aspek evaluation, hanya memeriksa kembali hasil yang telah peroleh dan memperbaiki kesalahan hasil saja. Siswa E dan Siswa F pada aspek planning, tidak menuliskan hal yang diketahui dan ditanyakan dari soal, tidak menyusun strategi sebelum mengerjakan soal, dan tidak dapat menduga hasil akhir dari soal. Pada aspek monitoring, mengerjakan soal tidak sesuai dengan rencana atau strategi yang telah disusun, sehingga tidak memeriksa kesesuaian langkah dengan tujuan, dan tidak dapat mengatasi kesulitan selama mengerjakan soal. Sehingga pada aspek evaluation, tidak memeriksa kembali hasil yang telah peroleh, dan tidak dapat memperbaiki kesalahan langkah atau hasil.

Teknik think aloud dilakukan setelah wawancara dengan mengerjakan ulang hasil jawaban dan meminta subjek untuk mengeraskan suara dari proses berpikirnya saat mengerjakan soal. Metode ini dilakukan dengan meminta subjek penelitian untuk menyelesaikan masalah sekaligus menceritakan proses berpikirnya (Susanto, 2016). Hal ini untuk mengetahui proses berpikir siswa yang 
berupa metacognitive control yang terdiri dari aspek planning, monitoring dan evaluation. Teknik ini menggunakan perekam suara sehinggga proses berpikir siswa dapat dianalisa lebih mendalam. Matode think aloud merupakan salah satu cara khusus mengungkap proses berpikir seseorang (Susanto, 2016).

Rekaman suara proses berpikir terhadap siswa bergaya kognitif reflektif diwakili oleh Siswa A, telah menunjukkan aspek planning sebagaimana isi rekaman "... yang ini saya kalikan, hasilnya bisa buat persamaan dengan hasil yang ini". Siswa A juga menunjukkan aspek monitoring seperti "dua $q$ dan tiga $p$ ini dikumpulkan, ini $x y$ xy". Sedangkan aspek evaluation ditunjukkan dengan gerakan tangan yang menunjuk ulang dari proses awal hingga hasil akhir. Sedangkan rekaman suara terhadap siswa bergaya kognitif impulsif diwakili oleh Siswa F yang tidak menunjukkan aspek planning, monitoring dan evaluation dengan baik. Dari hasil rekaman "dua x kali px, dua $p$ x kuadrat. Dua x kali qy, dua x qy. Tiga y kali $p x$, px tiga y. tiga y kali qy, tiga q y kuadrat, ...”. Hal ini menunjukkan bahwa Siswa F hanya melakukan operasioanl dalam perkalian bentuk aljabar, tidak memahami kesalahannya, dan tidak melakukan evaluation terhadap jawabannya.

Adapun hasil penelitian berdasarkan ketercapaian kontrol metakognitif siswa dapat dijelaskan pada tabel 3, 4, dan 5 sebagai berikut.

Tabel 3. Ketercapaian Indikator Metakognisi siswa untuk Aspek Planning

\begin{tabular}{|c|c|c|}
\hline Gaya Kognitif & Indikator Pencapaian & Kreteria \\
\hline Reflektif & $\begin{array}{l}\text { Siswa A: } \\
\text { Melakukan perencanaan yaitu menuliskan yang } \\
\text { diketahui dan yang ditanyakan dengan benar, } \\
\text { menyusun rencana penyelesaian, dan dapat } \\
\text { menentukan tujuan/ hasil akhir } \\
\text { Siswa B: } \\
\text { Melakukan perencanaan yaitu menuliskan yang } \\
\text { diketahui dan yang ditanyakan dengan benar, namun } \\
\text { belum menyusun rencana penyelesaian dengan baik, } \\
\text { tetapi sudah dapat menentukan tujuan/ hasil akhir } \\
\text { Siswa } C \text { : } \\
\text { Melakukan perencanaan yaitu menuliskan yang } \\
\text { diketahui dan yang ditanyakan dengan benar, } \\
\text { menyusun rencana penyelesaian, namun belum } \\
\text { dapat menentukan tujuan/ hasil akhir }\end{array}$ & $\begin{array}{c}\text { Cukup } \\
\text { Baik }\end{array}$ \\
\hline Impulsif & $\begin{array}{l}\text { Siswa D: } \\
\text { Melakukan perencanaan yaitu menuliskan yang } \\
\text { diketahui dan yang ditanyakan dengan benar, } \\
\text { menyusun rencana penyelesaian, namun belum } \\
\text { dapat menentukan tujuan/ hasil akhir }\end{array}$ & $\begin{array}{c}\text { Cukup } \\
\text { Baik }\end{array}$ \\
\hline
\end{tabular}




\begin{tabular}{|c|c|c|}
\hline Gaya Kognitif & Indikator Pencapaian & Kreteria \\
\hline & $\begin{array}{l}\text { Siswa } \boldsymbol{E} \text { : } \\
\text { Belum melakukan perencanaan yaitu tidak } \\
\text { menuliskan yang diketahui dan yang ditanyakan } \\
\text { dengan benar, tidak menyusun rencana } \\
\text { penyelesaian, dan tidak dapat menentukan tujuan/ } \\
\text { hasil akhir } \\
\text { Siswa F: } \\
\text { Belum melakukan perencanaan yaitu tidak } \\
\text { menuliskan yang diketahui dan yang ditanyakan } \\
\text { dengan benar, tidak menyusun rencana } \\
\text { penyelesaian, dan tidak dapat menentukan hasil } \\
\text { akhir. Sehingga S-6 memenuhi indikator aspek } \\
\text { perencanaan dengan kategori tidak baik. }\end{array}$ & $\begin{array}{c}\text { Tidak } \\
\text { Baik }\end{array}$ \\
\hline
\end{tabular}

Tabel 4. Ketercapaian Indikator Metakognisi siswa untuk Aspek Monitoring

\begin{tabular}{|c|c|c|}
\hline $\begin{array}{c}\text { Gaya } \\
\text { Kognitif }\end{array}$ & Indikator Pencapaian & Kreteria \\
\hline Reflektif & $\begin{array}{l}\text { Siswa A: } \\
\text { Melakukan pemantauan yaitu melakukan langkah- } \\
\text { langkah dengan tepat sesuai rencana, memantau } \\
\text { kebenaran langkah dan penghitungan yang } \\
\text { dilakukan, dan mengatasi kesulitan selama } \\
\text { melakukan langkah dan penghitungan }\end{array}$ & Baik \\
\hline & $\begin{array}{l}\text { Siswa B: } \\
\text { Melakukan pemantauan yaitu melakukan langkah- } \\
\text { langkah dengan tepat sesuai rencana, memantau } \\
\text { kebenaran langkah dan penghitungan yang } \\
\text { dilakukan, dan mengatasi kesulitan selama } \\
\text { melakukan langkah dan penghitungan }\end{array}$ & Baik \\
\hline & $\begin{array}{l}\text { Siswa C: } \\
\text { Melakukan pemantauan yaitu melakukan langkah- } \\
\text { langkah dengan tepat sesuai rencana, memantau } \\
\text { kebenaran langkah dan penghitungan yang } \\
\text { dilakukan, namun belum bisa mengatasi kesulitan } \\
\text { selama melakukan langkah dan penghitungan }\end{array}$ & $\begin{array}{l}\text { Cukup } \\
\text { Baik }\end{array}$ \\
\hline
\end{tabular}




\begin{tabular}{|c|c|c|}
\hline $\begin{array}{c}\text { Gaya } \\
\text { Kognitif }\end{array}$ & Indikator Pencapaian & Kreteria \\
\hline \multirow[t]{3}{*}{ Impulsif } & $\begin{array}{l}\text { Siswa D: } \\
\text { Belum melakukan pemantauan yaitu tidak } \\
\text { melakukan langkah-langkah dengan tepat sesuai } \\
\text { rencana, tidak memantau kebenaran langkah dan } \\
\text { penghitungan yang dilakukan, dan tidak mengatasi } \\
\text { kesulitan selama melakukan langkah dan } \\
\text { penghitungan }\end{array}$ & $\begin{array}{l}\text { Tidak } \\
\text { Baik }\end{array}$ \\
\hline & $\begin{array}{l}\text { Siswa } \boldsymbol{E} \text { : } \\
\text { Belum melakukan pemantauan yaitu tidak } \\
\text { melakukan langkah-langkah dengan tepat sesuai } \\
\text { rencana, tidak memantau kebenaran langkah dan } \\
\text { penghitungan yang dilakukan, dan tidak mengatasi } \\
\text { kesulitan selama melakukan langkah dan } \\
\text { penghitungan }\end{array}$ & $\begin{array}{l}\text { Tidak } \\
\text { Baik }\end{array}$ \\
\hline & $\begin{array}{l}\text { Siswa F: } \\
\text { Belum melakukan pemantauan yaitu tidak } \\
\text { melakukan langkah-langkah dengan tepat sesuai } \\
\text { rencana, tidak memantau kebenaran langkah dan } \\
\text { penghitungan yang dilakukan, dan tidak mengatasi } \\
\text { kesulitan selama melakukan langkah dan } \\
\text { penghitungan }\end{array}$ & $\begin{array}{l}\text { Tidak } \\
\text { Baik }\end{array}$ \\
\hline
\end{tabular}

Tabel 5. Ketercapaian Indikator Metakognisi siswa untuk Aspek Evaluation

\begin{tabular}{|c|c|c|}
\hline $\begin{array}{c}\text { Gaya } \\
\text { Kognitif }\end{array}$ & Indikator Pencapaian & Kreteria \\
\hline \multirow[t]{3}{*}{ Reflektif } & $\begin{array}{l}\text { Siswa A: } \\
\text { Melakukan evaluasi yaitu memeriksa kebenaran } \\
\text { langkah penyelesaian, memeriksa kebenaran hasil } \\
\text { yang diperoleh, dan melakukan evaluasi pencapaian } \\
\text { tujuan }\end{array}$ & Baik \\
\hline & $\begin{array}{l}\text { Siswa B: } \\
\text { Melakukan evaluasi yaitu memeriksa kebenaran } \\
\text { langkah penyelesaian, memeriksa kebenaran hasil } \\
\text { yang diperoleh, dan melakukan evaluasi pencapaian } \\
\text { tujuan }\end{array}$ & Baik \\
\hline & $\begin{array}{l}\text { Siswa } \boldsymbol{C} \text { : } \\
\text { Melakukan evaluasi yaitu memeriksa kebenaran } \\
\text { langkah penyelesaian, memeriksa kebenaran hasil } \\
\text { yang diperoleh, dan melakukan evaluasi }\end{array}$ & Baik \\
\hline
\end{tabular}




\begin{tabular}{clc}
\hline $\begin{array}{c}\text { Gaya } \\
\text { Kognitif }\end{array}$ & \multicolumn{1}{c}{ Indikator Pencapaian } & Kreteria \\
\hline Impulsif & $\begin{array}{l}\text { Siswa } \boldsymbol{D} \text { : } \\
\text { Melakukan evaluasi, namun belum memeriksa } \\
\text { kebenaran langkah penyelesaian, namun sudah } \\
\text { memeriksa kebenaran hasil yang diperoleh, dan } \\
\text { melakukan evaluasi pencapaian tujuan }\end{array}$ & $\begin{array}{c}\text { Cukup } \\
\text { Baik }\end{array}$ \\
& $\begin{array}{l}\text { Siswa } \boldsymbol{E} \text { : } \\
\text { Belum melakukan evaluasi yaitu tidak memeriksa } \\
\text { kebenaran langkah penyelesaian, tidak memeriksa } \\
\text { kebenaran hasil yang diperoleh, dan tidak melakukan } \\
\text { evaluasi pencapaian tujuan }\end{array}$ & Tidak \\
& $\begin{array}{l}\text { Baik } \\
\text { Siswa } \boldsymbol{F} \text { : }\end{array}$ & \\
& $\begin{array}{l}\text { Belum melakukan evaluasi yaitu tidak memeriksa } \\
\text { kebenaran langkah penyelesaian, tidak memeriksa } \\
\text { kebenaran hasil yang diperoleh, dan tidak } \\
\text { melakukan evaluasi pencapaian tujuan }\end{array}$ & Tidak \\
& & Baik \\
& & \\
\hline
\end{tabular}

Berdasarkan hasil analisi pada tabel 3, 4, dan 5 diatas, menunjukkan bahwa dari 3 aspek metakognisi siswa dengan 6 subjek, menunjukkan bahwa terdapat 6 kategori baik (33\%), terdapat 5 kategori cukup baik (28\%), dan 7 kategori tidak baik (39\%). Kategori kemampuan metakognisi siswa, nampak pada gambar 5 berikut.

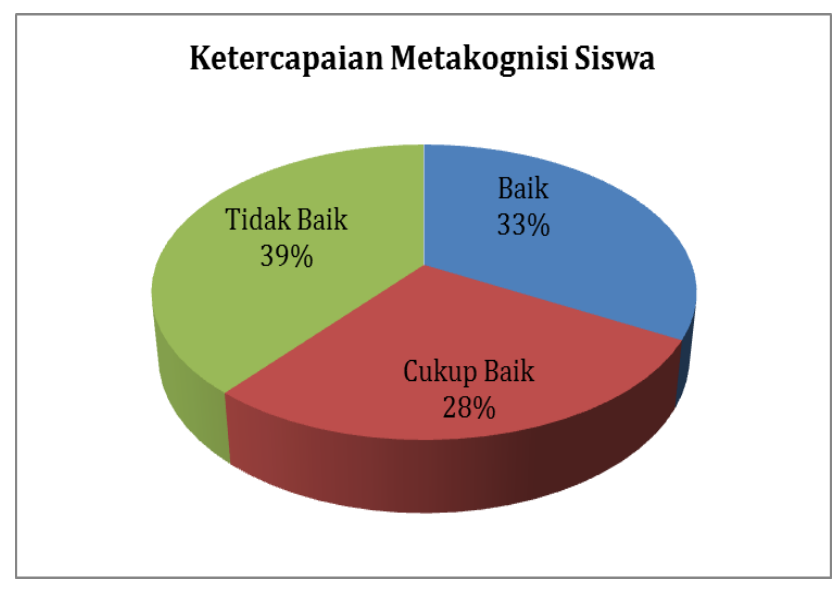

Gambar 4. Kategori Ketercapaian Metakognisi Siswa

Dengan demikian, untuk mengatasi dan meningkatkan kemampuan metakognisi siswa terutama terhadap kategori tidak baik, upaya yang dapat dilakukan antara lain: (a) menemukan penyebab dari aspek yang tidak baik; (b) meningkatkan kepedulian dalam learning community; (c) memberikan perhatian lebih dan bantuan dari teman kelompok; (d) melatih dan meningkatkan 
kemampuan metakognisinya ke level yang lebih tinggi; dan (e) meningkatkan implementasi LSLC dalam kurikulum sekolah. Menurut Saito \& Atencio (2015) mengatakan bahwa LSLC bertujuan untuk mengubah struktur pelajaran, sekolah, dan budaya mereka, agar dapat membuat 'kasat mata yang terlihat (invisible visible)' dan untuk memfasilitasi penggabungan mereka ke dalam komunitas sekolah. Hal penelitian ini memeperkuat hasil penelitian yang didapat oleh Lee \& Tan (2020) menunjukkan bahwa Lesson Study dapat bentuk pengembangan profesional di mana para guru secara kolaboratif merancang pelajaran penelitian dan meningkatkan pengajaran menggunakan bukti yang telah mereka kumpulkan tentang pembelajaran dan pengembangan siswa. Sehingga semakin profesional seorang guru maka akan berdampak positif pada kemampuan metakognisi siswanya karena dalam proses pembelajarannya tentunya seorang guru akan mengajak siswa selalu untuk mengasah proses berpikitnya.

Kemampuan metakognitif dapat dipantau dari jurnal belajar, diterapkan selama studi pelajaran untuk komunitas belajar, disiapkan oleh guru (Hobri et al., 2018). Menurut Gama (2005) mengatakan bahwa metakognisi adalah proses berpikir tingkat tinggi yang bertanggung jawab untuk kontrol aktif atas proses kognitif. Menurut Abidin \& Tohir (2019) mengatakan bahwa berpikir tingkat tinggi tumbuh ketika seorang individu menghadapi masalah atau persoalan yang belum pernah dipecahkan atau Higher Order Thinking Skills (HOTS) terjadi ketika seseorang mengambil informasi baru dan informasi yang tersimpan dalam memori saling berhubungan atau menata kembali dan memperluas informasi ini untuk mencapai suatu tujuan atau menemukan jawaban yang mungkin dalam situasi membingungkan. Sehingga untuk menumbuhkembangkan berpikir HOTS dalam pemeblajaran dikelas, maka guru harus fokus pada materi yang akan didiskusikan dalam kelas, melalui pembelajaran HOTS yang bersumber dari kelompok diskusi siswa. Kemudian, guru menyusun instrumen penilai berdasarkan penerapan pembelajaran HOTS yang dilakukan dalam kelas (Mukhlis \& Tohir, 2019). Menurut As'ari, Tohir, Valentino, Imron, \& Taufiq (2017) mengatakan bahwa pembelajaran HOTS merupakan pembelajaran berorientasi pada keterampilan berpikir tingkat tinggi, peran guru tidak banyak menerangkan, sebaliknya guru banyak melakukan stimulasi pertanyaan untuk mendorong keluarnya pikiran-pikiran orsinil siswa. Dengan demikian, proses berpikir tingkat tinggi siswa akan meningkat dan berkembang dengan sendirinya seiring aktifitas mental dalam pengetahuan metakognisinya yang didapat dalam pembelajaran HOTS.

Oleh karena itu dapat disimpulkan bahwa, analisis metakognisi siswa guna menjelaskan keterampilan matakognisi siswa berdasarkan komponen-komponen metakognisi, berupa pengetahuan metakognisi dan kontrol metakognisi. Ditinjau dari gaya kognitif reflektif atau impulsif diharapkan kendala belajar siswa dapat diketahui dan teratasi. Implementasi LSLC dalam pembelajaran menggunakan model kolaboratif sehingga siswa dapat saling belajar dan berinteraksi melalui media belajar. Kemudian guru secara kolaborasi melakukan kajian terhadap pembelajaran yang dilaksanakan. 


\section{KESIMPULAN}

Berdasarkan hasil penelitian yang telah diuraikan sebelumnya dan hasil pembahasan yang telah dikaji sebelumnya, maka dapat disimpulkan bahwa; (1) hasil penelitian ini menunjukkan bahwa siswa yang memiliki pengetahuan metakognitif yang baik menjadi lebih efektif dan efisien ketika mereka menerapkan aspek metakognitif. Oleh karena itu, para siswa yang memiliki pengetahuan metakognitif yang buruk, mereka mengalami kesulitan ketika mereka menerapkan aspek metakognitif; (2) kontribusi pembelajaran pemecahan masalah matematika berdasarkan LSLC sangat membantu dalam meningkatkan kemampuan metakognisi siswa untuk individu, dalam kelompok dan secara klasik; (3) hasil penelitian menunjukkan bahwa siswa bergaya kognitif reflektif, skor yang diperoleh lebih baik dengan pengguaan waktu yang relatif lebih lama. Sedangkan siswa bergaya kognitif impulsif, skor yang diperoleh lebih rendah dengan penggunaan waktu yang relatif lebih cepat; dan (4) Siswa bergaya kognitif reflektif, dapat melakukan aspek metakognisi dengan baik. Sedangkan siswa bergaya kognitif impulsif, tidak dapat melakukan aspek metakognisi dengan baik.

Adapun bagi siswa sebaiknya selalu mengambil hikmah dari pembelajaran yang didapat dalam kelas, sehingga dalam menghadapi soal cerita akan lebih mudah memahami maksud dan tujuan dari soal yang diberikan. Siswa harus selalu aktif dalam kegiatan pemebelajaran sehingga dapat meningkatkan kemampuan metakognisinya ke level yang lebih tinggi. Sedangkan bagi tenaga pendidik atau para peneliti agar dapat melakukan inovasi dalam pembelajarannya setiap waktu dengan ciri khas tertentu yang membuat siswa nyaman didalam kelas. Hal ini dimaksudkan agar siswa benar-benar fokus terhadap pelajaran yang dibahas, karena hasil dalam penelitian ini masih memiliki kelemahan pada bagaian hubungan dan pengeruhnya antara tingkat kemampuan metakognisi siswa dengan tingkat keterampilan abad 21. 


\section{DAFTAR PUSTAKA}

Abidin, Z., \& Tohir, M. (2019). Keterampilan Berpikir Tingkat Tinggi dalam Memecahkan Deret Aritmatika Dua Dimensi Berdasarkan Taksonomi Bloom. Alifmatika: Jurnal Pendidikan Dan Pembelajaran Matematika, 1(1), 44-60. https://doi.org/10.35316/alifmatika.2019.v1i1.44-60

Andriyani, A. (2018). Analisis Kesalahan Siswa dalam Menyelesaikan Soal Cerita pada Materi Program Linear Ditinjau dari Gaya Kognitif Siswa. Pendekar: Jurnal Pendidikan Berkarakter, 1(1), 16-22.

Anggraena, Y. (2019). Pengembangan Kurikulum Matematika untuk Meningkatkan Kemampuan Siswa dalam Penalaran dan Pemecahan Masalah. Alifmatika: Jurnal Pendidikan Dan Pembelajaran Matematika, 1(1), 15-27.

As'ari, A. R., Tohir, M., Valentino, E., Imron, Z., \& Taufiq, I. (2017). Buku Guru Matematika (Revisi). Jakarta: Pusat Kurikulum dan Perbukuan, Balitbang, Kemendikbud.

Bjuland, R., \& Mosvold, R. (2015). Lesson study in teacher education: Learning from a challenging case. Teaching and Teacher Education, 52, 83-90.

Cintamulya, I., \& Mawartiningsih, L. (2019). Critical Thinking Ability after ProjectBased Learning: A Comparative Study on Students Who Have Different Cognitive Styles. Journal of Physics: Conference Series, 1422(1), 12039. IOP Publishing.

Fadiana, M. (2016). Perbedaan kemampuan menyelesaikan soal cerita antara siswa bergaya kognitif reflektif dan impulsif. Journal of Research and Advances in Mathematics Education, 1(1), 79-89.

Faradillah, A., Hadi, W., \& Tsurayya, A. (2018). Pre-service mathematics teachers' reasoning ability in solving mathematical non-routine problem according to cognitive style. Journal of Physics: Conference Series, 948(1), 12006. IOP Publishing.

Fitriyah, I. (2015). Metakognisi Siswa SMP dalam Menyelesaikan Soal Cerita Ditinjau dari Kemampuan Matematika dan Gender. MATHEdunesa, 3(3).

Gama, C. A. (2005). Integrating metacognition instruction in interactive learning environments. University of Sussex.

Hobri, H., Romlah, S., Prihandoko, A. C., Safitri, J., \& Nazareth, E. (2018). Students' metacognitive ability in mathematical problem-solving learning based on lesson study for learning community (LSLC). Journal of Physics: Conference Series, 1088(1), 12064. IOP Publishing.

Hobri, H., Septiawati, I., \& Prihandoko, A. C. (2018). High-order thinking skill in contextual teaching and learning of mathematics based on lesson study for learning community. International Journal of Engineering \& Technology, 7(3), 1576-1580.

Lee, L. H. J., \& Tan, S. C. (2020). Teacher learning in Lesson Study: Affordances, disturbances, contradictions, and implications. Teaching and Teacher Education, 89, 102986. 
Mahdavi, M. (2014). An overview: Metacognition in education. International Journal of Multidisciplinary and Current Research, 2(6), 529-535.

Maswar, M. (2019). Strategi Pembelajaran Matematika Menyenangkan Siswa (MMS) Berbasis Metode Permainan Mathemagic, Teka-teki Dan Cerita Matematis. Alifmatika: Jurnal Pendidikan Dan Pembelajaran Matematika, 1(1), 28-43. https://doi.org/10.35316/alifmatika.2019.v1i1.28-43

Mukhlis, M., \& Tohir, M. (2019). Instrumen Pengukur Creativity and Innovation Skills Siswa pada Era Revolusi Industri 4.0. Indonesian Journal of Mathematics and Natural Science Education, 1(1), 65-73. https://doi.org/10.31219/osf.io/g2hcr

Nasriadi, A. (2019). Profil Pemecahan Masalah Matematika Siswa SMP Ditinjau dari Gaya Kognitif Reflektif dan Impulsif. MAJU: Jurnal Ilmiah Pendidikan Matematika, 2(2), 1-27.

P21. (2014). Learning for the 21st Century: A Report and MILE Guide for. Retrieved from http://www.21stcenturyskills.org

Purwaningsih, W. I., Astuti, E. P., Nugraheni, P., \& Rizkyaningtyas, N. P. (2019). Characteristics of intuitive thinking in solve mathematical issue based on cognitive style. Journal of Physics: Conference Series, 1254(1), 12081. IOP Publishing.

Saiful. (2019). Analisis Metakognisi Siswa Melalui Jumping Task Berbasis Lesson Study For Learning Community. Tesis. Magister Pendidikan Matematika Universitas Jember.

Saiful, S., Susanto, S., \& Hobri, H. (2019). The Students' Metacognition Analysis Through Jumping Task Based Onlesson Study for Learning Community. Journal of Physics: Conference Series, 1265(1), 012002. https://doi.org/10.1088/1742-6596/1265/1/012002

Saito, E., \& Atencio, M. (2015). Lesson study for learning community (LSLC): Conceptualising teachers' practices within a social justice perspective. Discourse: Studies in the Cultural Politics of Education, 36(6), 795-807.

Semiawan, C. R. (2018). Metode penelitian kualitatif: jenis, karakteristik dan keunggulannya. Jakarta: PT Gramedia Widiasarana Indonesia.

Susanto, S. (2016). Mengidentifikasi Kesalahan Mahasiswa dalam Membuktikan Teorema-Teorema Kesebangunan Segitiga dengan Metode Think Aload. Prosiding Seminar Nasional Pendidikan Matematika 2016, 118-122.

Tohir, M., Abidin, Z., Dafik, D., \& Hobri, H. (2018). Students Creative Thinking Skills in Solving Two Dimensional Arithmetic Series Through Research-Based Learning. Journal of Physics: Conference Series, 1008(1), 012072. https://doi.org/10.1088/1742-6596/1008/1/012072

Tohir, Mohammad. (2017). Pengembangan Bahan Ajar Olimpiade Matematika Berdasarkan Model Pemecahan Masalah untuk Meningkatkan Kemampuan Penalaran Matematis Siswa. In Tesis. Magister Pendidikan Matematika Universitas Jember. https://doi.org/10.13140/RG.2.2.31121.79200 
Tohir, Mohammad. (2019). Keterampilan Berpikir Kreatif Siswa dalam Menyelesaikan Soal Olimpiade Matematika Berdasarkan Level Metakognisi. Alifmatika: Jurnal Pendidikan Dan Pembelajaran Matematika, 1(1), 1-14. https://doi.org/10.35316/alifmatika.2019.v1i1.1-14

Tohir, Mohammad, Susanto, Hobri, Suharto, \& Dafik. (2018). Students' Creative Thinking Skills in Solving Mathematics Olympiad Problems Based on ProblemSolving Polya and Krulik-Rudnick Model. Advanced Science Letters, 24(11), 8361-8364. https://doi.org/10.1166/asl.2018.12563

Tohir, Mohammad, \& Wardani, A. (2017). Analisis Kemampuan Calon Guru Matematika dalam Menerapkan Pendekatan Saintifik Berdasarkan Kurikulum 2013. Prosiding Seminar Nasional Pendidikan Matematika, 2, 431-446. https://doi.org/10.13140/RG.2.2.12666.85444

Utami, R. E., \& Indriana, K. (2018). Metacognitive ability of male students: difference impulsive-reflective cognitive style. Journal of Physics: Conference Series, 983(1), 12118. IOP Publishing.

Warli, W. (2014). Kreativitas Siswa SMP yang Bergaya Kognitif Reflektif atau Impulsif dalam Memecahkan Masalah Geometri. Jurnal Pendidikan Dan Pembelajaran (JPP), 20(2), 190-201.

Widadah, S., Afifah, D. S. N., \& Pos, J. J. K. (2013). Profil Metakognisi Siswa dalam Menyelesaikan Soal Sistem Persamaan Linear Dua Variabel Berdasarkan Gaya Kognitif. Jurnal Pendidikan Matematika STKIP PGRI Sidoarjo, 1(1), 13-24. 